DOI: https://doi.org/10.34069/AI/2021.43.07.2

How to Cite:

Brilon, A., Kadyseva, A., Khabibullin, R., Usmanova, R., \& Zinchenko, A. (2021). The impact of consumer cooperatives on the living standards of the population in Russia. Amazonia Investiga, 10(43), 20-31. https://doi.org/10.34069/AI/2021.43.07.2

\title{
The impact of consumer cooperatives on the living standards of the population in Russia
}

\section{Влияние потребительской кооперации на уровень жизни населения в России}

Received: June 10, 2021

\section{Abstract}

The socio-economic development of Russia in recent years has significantly slowed down, which is caused by both external factors (a difficult geopolitical situation, sanctions wars, the economic confrontation between leading world economic powers) and internal factors (poverty, low efficiency of the economy, a weak innovation environment). In these conditions, it is necessary to find various ways to stimulate the economic and social development of the country and regions. This paper discusses the development of cooperation as a way to develop economic relations and improve living standards. The aim of the study is to reveal the relationship between consumer co-operation and the standard of living of the population, and to determine its impact on the economy. The main research methods were analysis and synthesis, generalization, and the case method. This study used data from the Federal State Statistics Service of the Russian Federation, analytical reviews on the development of cooperation in Russia, and data from the Central Union of Russia. As a result of the study, the influence of cooperation on the growth of living standards of the population has been identified, some recommendations have been made on the
Accepted: July 28, 2021

Written by:

Andrey Brilon ${ }^{3}$

https://orcid.org/0000-0002-3691-3421

Anastasia Kadyseva ${ }^{4}$

https://orcid.org/0000-0001-8703-5684

Rinat Khabibullin ${ }^{5}$

https://orcid.org/0000-0003-0338-0013

Rezida Usmanova ${ }^{6}$

https://orcid.org/0000-0002-7913-2246

Alexander Zinchenko ${ }^{7}$

https://orcid.org/0000-0001-7971-4572

\section{Аннотация}

В последние годы социально-экономическое развитие России существенно замедлилось, что обусловлено как внешними факторами (сложная геополитическая ситуация, санкционные войны, экономическое противостояние ведущих мировых экономических держав), так и внутренними (бедность, низкая эффективность экономики, слабая инновационная среда). В этих условиях необходимо найти различные пути стимулирования экономического и социального развития страны и регионов. В данной работе рассматривается развитие кооперации как способ развития экономических отношений и повышения уровня жизни. Цель исследования - раскрыть связь потребительской кооперации с уровнем жизни населения, а также определить его влияние на экономику. Основными методами исследования были анализ и синтез, обобщение, а также метод кейса. В исследовании использовались данные Федеральной службы государственной статистики Российской Федерации, аналитические обзоры развития потребительской кооперации в России, данные Центрального Союза России. В результате

\footnotetext{
${ }^{3} \mathrm{PhD}$ in Economics, Professor, Russian University of Cooperation, Russia.

${ }^{4}$ Doctor of Biology, Professor, Tyumen Industrial University, Russia.

5 PhD in Economics, Associate Professor, Bashkir State University, Ufa, Russia.

${ }^{6}$ Doctor of Law, Professor, Bashkir State University, Sterlitamak, Russia.

${ }^{7} \mathrm{PhD}$ in Economics, Associate Professor, Moscow Aviation Institute, Russia.
} 


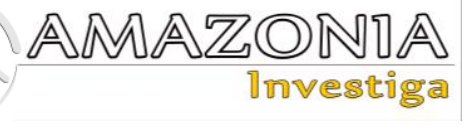

development of cooperation in Russia.

Keywords: Cooperation, poverty, living standards, rural population.

исследования было выявлено влияние потребительской кооперации на рост уровня жизни населения, даны некоторые рекомендации по развитию потребительской кооперации в России.

Ключевые слова: Сотрудничество, бедность, уровень жизни, сельское население.

\section{Introduction}

Currently, the socio-economic development of the Russian Federation is undermined by a number of factors that can be divided into two large groups: external and internal.

One of the most important factors of the first group is foreign policy. The fundamental contradictions in the socio-cultural, economic, political and military spheres between Russia and other countries, primarily with the USA and the countries of the European Union, have led to the imposition of sanctions and increased tension, including in the military sphere. In this regard, the solution of the tasks of ensuring the national security of the Russian Federation diverts significant funds and resources, which does not enable them to be spent in the required amount to solve the problems of national socio-economic development. The restrictions imposed on Russian organizations in international markets force them to seek new partners and increase the attractiveness of the domestic market.

Among the internal factors, in the authors' opinion, the low efficiency of the economy and a

weak innovation environment, and especially the problem of poverty in Russia should be highlighted. This choice is caused by the fact that in the modern economy, the main problem is not production, but the sale of goods and services. The poor cannot form a sufficient solvent demand, which negatively affects the development of the business that produces and sells goods in the domestic market (Rzhanitsyna, 2013).

According to Russian statistics, $20 \%$ of Russia's population lives below the poverty line. According to some estimates, one of the criteria for belonging to the middle class in Russia is a salary of 100 thousand rubles per month (Falyakhov, 2018). Meantime, an analysis of the data shown in Table 1 shows that the average monthly accrued wages of employees on average by types of activity in Russia is 49,348 rubles, and the threshold of 100 thousand rubles is exceeded only in 3 out of $54(5.5 \%)$ types of economic activity (Federal State Statistics Service, 2019).

Table 1.

Types of economic activity for which the average accrued wages of employees exceeded 100 thousand rubles as of June 2019

\begin{tabular}{|c|c|c|c|c|c|c|}
\hline & \multicolumn{3}{|c|}{ June 2019} & \multicolumn{3}{|c|}{ 1st half of 2019} \\
\hline & rubles & $\%$ to & & rubles & $\%$ to & \\
\hline & & $\begin{array}{l}\text { June } \\
2018\end{array}$ & $\begin{array}{l}\text { May } \\
2019\end{array}$ & & $\begin{array}{l}1 \text { st } \\
\text { half of } \\
2018\end{array}$ & $\begin{array}{l}\text { All-Russian } \\
\text { average } \\
\text { monthly } \\
\text { wages }\end{array}$ \\
\hline $\begin{array}{l}\text { Average accrued wages of employees, } \\
\text { including by industry: }\end{array}$ & 49,348 & 107.7 & 102.9 & 46,210 & 107.1 & $100 \%$ \\
\hline crude oil and natural gas production & 172,942 & 141.6 & 113.3 & 140,149 & 106.6 & 3.0 times \\
\hline tobacco production & 113,055 & 100.4 & 103.7 & 112,029 & 106.3 & 2.4 times \\
\hline air and space transport & 128,351 & 79.6 & 102.3 & 126,899 & 104.4 & 2.8 times \\
\hline
\end{tabular}

Source: Federal State Statistics Service (2019).

An analysis of the data presented in Table 1 allows one to conclude that the highest average wages of employees are observed in activities related to the oil and gas sector. Among them, the leaders are activities related to the extraction of crude oil and natural gas, in which both the highest absolute value (172,942 rubles) and the largest increase are observed compared to June 2018 (141.6\%). Also, the wages of employees exceeded 100 thousand rubles in types of 
activity: tobacco production, air and space transport.

It has already been noted above that poverty is one of the factors holding back the national socio-economic development. The poverty of the population is determined on the basis of a number of factors, the main of which are: the money income, the price level of goods and services, the tax burden, etc. The "living standards" indicator is a complex one that is used as one of the indicators characterizing the level of social-economic development of the region and the country as a whole.

Table 2 shows the values of indicators characterizing the living standards of the population of regions in accordance with the methodology of the leading rating agency of Russia - RIA Rating (https://riarating.ru). The table shows five outsider regions in terms of living standards and five leader regions.

Table 2.

Five outsider regions in terms of living standards in Russia and five leader regions.

\begin{tabular}{lllll}
\hline & $\begin{array}{l}\text { Ratio of money incomes of } \\
\text { people to the value of a fixed } \\
\text { set of consumer goods and } \\
\text { services at the end of 2017, } \\
\text { times }\end{array}$ & $\begin{array}{l}\text { Unemployment } \\
\text { rate at the end of } \\
2017, \%\end{array}$ & $\begin{array}{l}\text { Life } \\
\text { expectancy } \\
\text { at birth, } \\
\text { years }\end{array}$ & $\begin{array}{l}\text { Infant mortality } \\
\text { rate at the end of } \\
\text { 2017, number of } \\
\text { children dying of } \\
\text { age up to 1 year, } \\
\text { per 1,000 births }\end{array}$ \\
\hline $\begin{array}{l}\text { Republic of Tuva } \\
\text { Republic of }\end{array}$ & 1.05 & 18.3 & 66 & 8.8 \\
$\begin{array}{l}\text { Kalmykia } \\
\text { Altai Republic }\end{array}$ & 1.19 & 10.0 & 74 & 4.8 \\
$\begin{array}{l}\text { Karachayevo- } \\
\text { Circassian Republic }\end{array}$ & 1.20 & 12.0 & 71 & 9.6 \\
$\begin{array}{l}\text { Republic of } \\
\text { Ingushetia }\end{array}$ & 1.23 & 13.5 & 76 & 6.9 \\
$\begin{array}{l}\text { Chukotka } \\
\text { Autonomous Area }\end{array}$ & 2.65 & 27.0 & 82 & 7.3 \\
$\begin{array}{l}\text { Sakhalin Region } \\
\text { Moscow city }\end{array}$ & 2.72 & 2.9 & 66 & 10.5 \\
$\begin{array}{l}\text { Yamal-Nenets } \\
\text { Autonomous Area }\end{array}$ & 2.87 & 6.0 & 70 & 4.7 \\
$\begin{array}{l}\text { Nenets Autonomous } \\
\text { Area }\end{array}$ & 3.53 & 1.4 & 78 & 5.7 \\
\hline \begin{tabular}{l} 
Source RIA Rating Agen \\
\hline
\end{tabular}
\end{tabular}

Source: RIA Rating Agency (2018).

Analyzing the socio-economic situation of five outsider regions in terms of living standards, it should be noted that:

- in all five regions, the share of the rural population is the largest (Federal State Statistics Service, 2019);

- the unemployment rate significantly exceeds the national average $(6.37 \%)$, and in the Republic of Ingushetia it was $27 \%$, which is the highest value in all regions of Russia;

- the life expectancy in the Republic of Tuva is 66 years (with the national average of 71.26 years) and is the minimum in the country.

A similar picture is observed in other regions with a large share of the rural population, with the exception of the black soil regions of the Central Federal District of the Russian Federation.
It should be noted that in all regions being the leaders in terms of living standards of the population, except Moscow, crude oil and natural gas are actively produced.

The share of the rural population in Russia is $34.1 \%$ (Statistical portal, 2019). The main activities of the rural population in Russia are traditionally plant growing and animal husbandry, hunting and the provision of related services in these areas, textiles manufacture, manufacture of wearing apparel, leather and leather goods, wood processing and manufacture of wood and cork products, except furniture, manufacture of straw products and weaving materials, manufacture of furniture, and HoReCa. Now, let us consider the level of wages for these types of economic activities (Table 3).

From the data in the table, it can be seen that the average wage for almost all types of activities in which the rural population is mainly involved is 


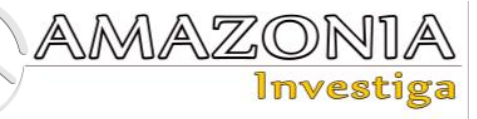

2 times lower than the average for Russia. In addition, the rural population is faced with problems of the lack of a sufficient number of jobs and the difficulty of selling agricultural products made at household plots, which also negatively affects people's incomes (Akhmetov et al., 2017).

Thus, increasing the incomes of rural inhabitants, leading to an increase in their living standards, is an important task for the successful socio-economic development of the regions and the country as a whole. Various state and non-state structures and organizations are involved in solving this problem.

Table 3.

Average wages by types of economic activity in which the rural population is predominantly employed as of June 2019

\begin{tabular}{|c|c|c|c|c|c|c|}
\hline & \multicolumn{3}{|c|}{ June 2019} & \multicolumn{3}{|c|}{ 1st half of 2019} \\
\hline & rubles & $\%$ to & & rubles & $\%$ to & \\
\hline & & $\begin{array}{l}\text { June } \\
2018\end{array}$ & $\begin{array}{l}\text { May } \\
2019\end{array}$ & & $\begin{array}{l}\text { 1st half } \\
\text { of } 2018\end{array}$ & $\begin{array}{l}\text { All-Russian } \\
\text { average } \\
\text { monthly wages }\end{array}$ \\
\hline $\begin{array}{l}\text { Average wages, including by type } \\
\text { of economic activity } \\
\text { plant growing and animal }\end{array}$ & 49,348 & 107.7 & 102.9 & 46,210 & 107.1 & 100 \\
\hline $\begin{array}{l}\text { husbandry, hunting and the } \\
\text { provision of related services in } \\
\text { these areas }\end{array}$ & 28,387 & 110.2 & 99.3 & 26,369 & 110.0 & 57 \\
\hline textiles manufacture & 25,836 & 102.1 & 103.2 & 25,152 & 103.4 & 54 \\
\hline manufacture of wearing apparel & 20,201 & 100.5 & 102.7 & 19,787 & 105.4 & 43 \\
\hline $\begin{array}{l}\text { manufacture of leather and leather } \\
\text { goods }\end{array}$ & 27,195 & 105.3 & 108.3 & 25,265 & 108.1 & 55 \\
\hline $\begin{array}{l}\text { wood processing and manufacture } \\
\text { of wood and cork products, except } \\
\text { furniture, manufacture of straw } \\
\text { products and weaving materials }\end{array}$ & 28,892 & 107.4 & 102.2 & 27,988 & 109.0 & 61 \\
\hline furniture manufacture & 26,119 & 102.9 & 104.9 & 25,408 & 107.8 & 55 \\
\hline HoReCa & 28,624 & 104.6 & 99.6 & 27,770 & 105.3 & 60 \\
\hline
\end{tabular}

Source: Federal State Statistics Service (2019).

A co-operative is defined as "an autonomous association of persons united voluntarily to meet their common economic, social and cultural needs and aspirations through a jointly-owned and democratically-controlled enterprise" (International Co-operative Alliance, 1995). Cooperatives are created by farmers to achieve economies of scale and generate economic benefits by reducing costs through pooling capital and resources (Schram, 2007).

Co-operatives differ from traditional enterprises in their establishment goals, management methods and organizational structure (Drivas, \& Giannakas, 2006, 2007; Giannakas, \& Fulton, 2003, 2005; Fulton, \& Giannakas, 2001), although they share some characteristics of traditional firms (Ariyaratne et al., 1997). First, co-operatives are owned by members, while

\section{Literature Review}

One of the ways to solve the problem of rural poverty is rural cooperation (Ji et al., 2018).

Agricultural co-operatives in developing countries play an important role in improving the sustainability of agriculture in general and the economy of a territory in particular, because they help farmers adopt more modern and efficient technologies at lower cost and gain access to new customers by sharing costs between members of the co-operative (Kumar et al., 2015). 
example, Ploeg, 2008, 2013; Goodman et al., 2011; Marsden, 2012). The process of cooperation in Europe is actively taking place together with specialization and intensification of agricultural production, as well as industrial processing and distribution (Wiskerke, 2009).

Koopmans et al. (2018) argue that it is necessary to better understand how the co-operative approaches underlying this transition contribute to the sustainable development of agriculture by enhancing the socio-environmental sustainability of agri-food systems.

Thus, the active development of cooperation takes place both in developing countries and in developed ones. In this study, the authors will examine the issue of the impact of cooperation on increasing rural incomes and thereby addressing the issue of poverty.

The aim of the study is to reveal the relationship between consumer co-operation and the standard of living of the population, and to determine its impact on the economy. The hypothesis of the study is the provision that the development of rural cooperation allows solving employment issues, increasing sales of agricultural products, increasing the making of processed agricultural products, increasing rural incomes, and partially solving poverty issues.

\section{Methodology}

The main research methods were analysis and synthesis, generalization and the case method. This study used data from the Federal State Statistics Service of the Russian Federation, analytical reviews on the development of cooperation in Russia and data from the Central Union of Russia.

The case method is based on the Central Union of Russia. The Central Union of Russia is the largest association of consumer cooperation, the activity of which is of great scientific interest in terms of the further development of consumer cooperation in Russia.

One of the ways to improve living standards in rural areas is to organise procurement of agricultural products from the households. This study analyses the procurement activities of the Central Union of Russia.

The study was conducted in the following stages:

1. Firstly, the material and technical basis of The Central Union of Russia and its ability to engage in procurement activities was analyzed.

2. Then the dynamics of volume of agricultural products and raw materials procurement from the households was analyzed.

3. Then the development of cooperative relations in the regions of Russia was assessed.

4. At the end of the study the conclusions were made about the connection between consumer cooperation and the standard of living of the population, and the impact of consumer cooperation on the economy was determined.

\section{Results and Discussion}

The Central Union of Russia is a non-profit organization, which since 1898 has been the supreme coordinating body of consumer cooperation in Russia, defending the interests of representatives of voluntary unions of consumer associations of the country. The Central Union of Russia today is 2,300 consumer associations from 71 regions of Russia, which unite 111 regional consumer unions and over 1,500,000 members. Consumer co-operatives provide goods and services to residents of 89,000 settlements throughout Russia (About the Central Union of Russia, 2019).

The Central Union is active in and supports cooperation in the fields of trade, education and science, healthcare, interaction with state structures and authorities, and is also a participant in a number of socially significant projects in Russia and abroad. In addition, the Central Union of Russia is engaged in legislative activities aimed at supporting and developing the cooperative movement.

Consumer cooperation organizations in Russia have a developed network of shops, warehouses, pick-up points, and manufacturing enterprises. In total, the system of the Central Union of Russia includes 4,000 workshops for the making of products, 9,000 facilities for organizing the purchase of raw stock from the population, its storage and primary processing, as well as about 33,000 retail enterprises and 4,000 public catering services. On the basis of 13,000 stationary and mobile workshops, cooperators provide agricultural, personal and construction services to the population. Consumer cooperative organizations included in the system of the Central Union of Russia provide 130,000 permanent jobs throughout Russia (About the Central Union of Russia, 2019). 


\section{AMAZONDA \\ 1nvestiga}

Consumer cooperation organizations in Russia have own education system, with more than 100 years of history. It includes three federal universities: "Russian University of Cooperation", "Siberian University of Consumer Cooperation", "Belgorod University of Cooperation, Economics and Law", as well as 40 special educational institutions. In total, 70 thousand students are studying in consumer cooperation educational institutions in Russia. The Central Union of Russia regularly takes part in federal and regional projects aimed at improving the quality of education.

The Central Union has its own healthcare system - rest and treatment in any of the sanatoriums or medical institutions of the Central Union are available to everyone. At the same time, members have the opportunity to receive preferences.

Currently, the activities of consumer cooperation organizations are concentrated in rural areas and cover 89 thousand settlements, providing jobs for 200 thousand people (Pakhomov, 2014).

As noted earlier, one of the problems faced by the rural population is the difficulty in selling agricultural products produced at household plots. Consumer cooperation organizations carry out multidisciplinary activities, including procurement.

To carry out this activity in the system of consumer cooperation, there are pick-up points, storages, warehouses, slaughterhouses, as well as specialized vehicles, milk trucks and cattle trucks.

At the beginning of 2017, in the system of consumer cooperation of the Central Union of Russia for the purchase of meat and meat products there were 40 cattle trucks and 92 slaughterhouses; for milk - 106 milk tank trucks, 997 milk collection stations, 70 milk coolers (Table 4).

Table 4.

Material and technical facilities of the Central Union of Russia in the field of procurement of agricultural products and raw stock, 2016

\begin{tabular}{ll}
\hline Name of facility & Number \\
\hline Shops-bases & 9,620 \\
Specialized bases & 640 \\
Fermentation points & 49 \\
Picking vats & 168 \\
Mushroom cooking points & 14 \\
Dryers for medicinal and technical raw stock & 189 \\
Potato and vegetable storehouses & 285 \\
Refrigerators & 537 \\
Cattle trucks & 40 \\
Cattle slaughter houses & 92 \\
Milk tank trucks & 106 \\
Milk reception stations & 997 \\
Milk coolers & 70 \\
\hline
\end{tabular}

Source: Tkach and Balalova (2017).

Purchasing activity strengthens the relationship of consumer cooperation with agricultural producers. In 2017, consumer associations of the Central Union of Russia purchased 58.3 thousand tons of meat, 225.1 thousand tons of dairy and other products from agricultural producers (Table 5). 
Table 5.

Dynamics of the volume of purchases of agricultural products and raw stock by consumer cooperation organizations of the Central Union of Russia and some regional unions, thousand tons.

\begin{tabular}{|c|c|c|c|c|c|c|}
\hline \multirow{2}{*}{ Name } & \multicolumn{5}{|l|}{ Years } & \multirow{2}{*}{$\begin{array}{l}2017 \text { to } \\
2013(\%)\end{array}$} \\
\hline & 2013 & 2014 & 2015 & 2016 & 2017 & \\
\hline \multicolumn{7}{|c|}{ The Central Union, total: } \\
\hline Meat & 77.8 & 69.5 & 64.7 & 62.3 & 58.3 & 74.9 \\
\hline Milk & 258.0 & 251.2 & 221.9 & 219.8 & 225.1 & 87.2 \\
\hline Potato & 73.3 & 64.1 & 52.6 & 51.3 & 52.7 & 71.9 \\
\hline Vegetables & 81.0 & 70.2 & 57.8 & 53.6 & 52.5 & 64.8 \\
\hline $\begin{array}{l}\text { Fruits } \\
\text { including } \mathrm{T}\end{array}$ & 48.2 & 44.5 & 39.1 & 31.3 & 28.8 & 59.8 \\
\hline Meat & 0.092 & 0.058 & 0.046 & 0.040 & 0.040 & 43.5 \\
\hline Milk & 0.035 & 0 & 0.011 & 0.01 & 0.011 & 31.4 \\
\hline Potato & 0.092 & 0.050 & 0.028 & 0.022 & 0.028 & 30.4 \\
\hline Vegetables & 0.101 & 0.097 & 0.078 & 0.039 & 0.050 & 49.5 \\
\hline \multicolumn{7}{|c|}{$\begin{array}{l}\text { Fruits } \\
\text { including Altai }\end{array}$} \\
\hline Meat & 0.036 & 0.036 & 0.026 & 1.0 & 0.021 & 58.3 \\
\hline Milk & 0.045 & 0.041 & 0.036 & 0.33 & 0.021 & 46.7 \\
\hline Potato & 0.032 & 0.033 & 0.027 & 0.26 & 0.019 & 60.3 \\
\hline Vegetables & 0.029 & 0.036 & 0.032 & 0.25 & 0.021 & 72.4 \\
\hline \multicolumn{7}{|l|}{ Fruits } \\
\hline Meat & 0.254 & 0.1 & 0.136 & 0.175 & 0.180 & 70.9 \\
\hline Milk & 1.171 & 0.420 & 0.830 & 1.1 & 1.2 & 102.5 \\
\hline Potato & 0.534 & 0.235 & 0.510 & 0.65 & 0.730 & 136.7 \\
\hline Vegetables & 0.222 & 0.115 & 0.315 & 0.42 & 0.500 & 225.2 \\
\hline Fruits & 0.123 & 0.06 & 0.06 & 0.07 & 0.080 & 65.0 \\
\hline
\end{tabular}

Source: Tkach and Balalova (2017).

An analysis of the data given in Table 5 allows one to draw the following conclusions:

- over the period considered, there is a decrease in the volume of procurement activities in the Central Union as a whole by $12.8-40.2 \%$, depending on the type of procurement;

- similar trends are observed in the Tuvan Republican consumer union, with an even greater decline in the procurement volume (50.5-69.6\%). This region is the worst in Russia in terms of income and life expectancy, and also ranks second in terms of unemployment;

- the dynamics of the procurement activities of consumer cooperation organizations in the Altai Republic correspond to the general trend. At the same time, the decrease in milk purchases is stronger than in the whole Central Union $(46.7 \%$ versus $87.2 \%)$. The volume of purchases of vegetables exceeds the general indicator by $7.6 \%$;

- in the territory of the KarachayevoCircassian Republic, an increase in the volume of procurement activity is observed for all types of purchases under consideration except meat, i.e. the trend is the opposite of the general one in the Central Union. At the same time, this region has the best performance (out of the three examined) in three indicators characterizing the living standards out of four.

Thus, despite the fact that the volume of procurement activities of consumer cooperation organizations is not large, it has, along with other factors, a positive impact on the living standards of the rural population of Russia.

The decrease in procurement by consumer cooperation organizations is caused by several factors, including the following:

- reduction in the number of material and technical facilities necessary for the implementation of this activity;

- competition from other procurement players;

- lack of governmental policy measures seeking to support this type of activity of consumer cooperation organizations. 


\section{AMAZONDA \\ 1nvestiga}

For a number of reasons, since the end of the last century, there has been a steady tendency towards a reduction in the number of the material and technical facilities in consumer cooperation

Table 6.

Dynamics of the material and technical facilities of the main sectors of consumer cooperation in Russia (thousand objects, at the beginning of the year)

\begin{tabular}{|c|c|c|c|c|c|c|c|c|}
\hline No. & 2005 & 2007 & 2009 & 2011 & 2013 & 2015 & 2017 & $\begin{array}{l}2005 / \\
2017, \\
\text { times }\end{array}$ \\
\hline 1. Bases & 2.69 & 2.05 & 1.08 & 1.3 & 0.88 & 0.64 & 0.68 & 3.96 \\
\hline 2. Slaughterhouses & 0.22 & 0.29 & 0.18 & 0.16 & 0.13 & 0.09 & 0.09 & 2.44 \\
\hline $\begin{array}{l}\text { 3. Potato and } \\
\text { vegetables/fruits } \\
\text { storehouses }\end{array}$ & 1.55 & 0.90 & 0.41 & 0.40 & 0.33 & 0.28 & 0.27 & 5.74 \\
\hline $\begin{array}{l}\text { 4. Machine-operated } \\
\text { refrigerating } \\
\text { storehouses }\end{array}$ & 0.88 & 0.77 & 0.36 & 0.36 & 0.41 & 0.54 & 0.52 & 1.69 \\
\hline 5. Cattle trucks & 0.09 & 0.11 & 0.08 & 0.06 & 0.05 & 0.04 & 0.04 & 2.25 \\
\hline 6. Milk tank trucks & 0.19 & 0.25 & 0.18 & 0.16 & 0.14 & 0.11 & 0.10 & 1.9 \\
\hline
\end{tabular}

Source: Tkach and Balalova (2017).

An analysis of the data shown in Table 6 allows drawing the following conclusions:

- there is a negative trend for all types of considered material and technical facilities;

- a reduction in the number of facilities occurred within the range of 1.69 to 5.74 times;

- $\quad$ to the greatest extent, over the period under review, the number of potato and vegetables/fruits storehouses reduced (5.74 times), as well as the number of pick-up bases (3.96 times).

Such a reduction in the facilities required has led to the fact that at present, consumer cooperation organizations carry out procurement activities organizations in the field of procurement. Statistical data on the number of facilities are shown in Table 6.

Table 7.

Coverage of cooperative relations among the main categories of agricultural producers operating in the regions of the Russian Federation.

\begin{tabular}{|c|c|c|c|c|c|c|c|c|c|}
\hline Region & $\begin{array}{l}\text { Total } \\
\text { agricultural } \\
\text { organizations } \\
\text { (AOs) }\end{array}$ & $\begin{array}{l}\text { Including } \\
\text { ACC } \\
\text { members }\end{array}$ & $\begin{array}{l}\% \\
\text { AOs - } \\
\text { memb } \\
\text { ers of } \\
\text { ACCs }\end{array}$ & $\begin{array}{l}\text { Total } \\
\text { family } \\
\text { farms } \\
\text { (FFs) } \\
\text { and sole } \\
\text { traders } \\
\text { (STs) }\end{array}$ & $\begin{array}{l}\text { Including } \\
\text { ACC } \\
\text { members }\end{array}$ & $\begin{array}{l}\% \text { of FFs } \\
\text { and STs } \\
\text { - ACC } \\
\text { members }\end{array}$ & $\begin{array}{l}\text { Total } \\
\text { househ } \\
\text { old } \\
\text { plots } \\
\text { (HHPs) }\end{array}$ & $\begin{array}{l}\text { Including } \\
\text { ACC } \\
\text { members }\end{array}$ & $\begin{array}{l}\% \text { of } \\
\text { HHPs - } \\
\text { ACC } \\
\text { members }\end{array}$ \\
\hline $\begin{array}{l}\text { Karachayevo } \\
\text {-Circassian } \\
\text { Republic }\end{array}$ & 173 & 7 & 4.05 & 1,475 & 12 & 0.81 & 64,100 & 90 & 0.14 \\
\hline $\begin{array}{l}\text { Altai } \\
\text { Republic }\end{array}$ & 136 & 6 & 4.41 & 1,680 & 18 & 1.07 & 44,600 & 179 & 0.4 \\
\hline $\begin{array}{l}\text { Republic of } \\
\text { Tuva }\end{array}$ & 232 & 11 & 4.74 & 800 & 22 & 2.75 & 33,200 & 114 & 0.34 \\
\hline
\end{tabular}

Source: On the State of Rural Areas in the Russian Federation in 2016. Annual Report on the Results of Monitoring. (2018).

within the volumes necessary to load their processing capacities and sales opportunities through their distribution network. Thus, a significant increase in the volume of procurement activities by consumer cooperation organizations is greatly complicated. In addition, the development of procurement is hindered by the lack of a large consumer of procured products ready to purchase it stably over a long time.

Speaking about the competitors of consumer cooperation organizations in the field of procurement, agricultural consumer cooperatives (ACCs) should be noted first of all. Table 7 shows the ratios of the number of agricultural producers in general and ACC members in the regions examined earlier. 
Comparing the data given in Tables 5 and 7, one can conclude:

- the Republic of Tuva is the leader in the coverage of agricultural commodity producers with cooperative relations (5 out of 6 indicators);

- the worst indicators have been observed in the Karachayevo-Circassian Republic (5 out of 6 indicators)

- $\quad$ in the Republic of Tuva, the largest decrease in the volume of procurement activity among all the regions examined has been observed, while the coverage of agricultural producers by ACCs is more complete;

- the Karachayevo-Circassian Republic displays a significant increase in procurement activities, despite the fact that the participation of agricultural producers in ACCs is minimal.

Thus, one can conclude that competition from ACCs has a significant impact on the procurement volume by consumer cooperation organizations.

In the authors' opinion, the most complete view of the role of agricultural consumer cooperatives is ensured by comparing the volume of services they provide with the total output of the main types of agricultural products. Figure 1 shows the dynamics of sales of agricultural products in comparison with sales through co-operatives (services provided to agricultural producers not being the members of co-operatives are also taken into account).

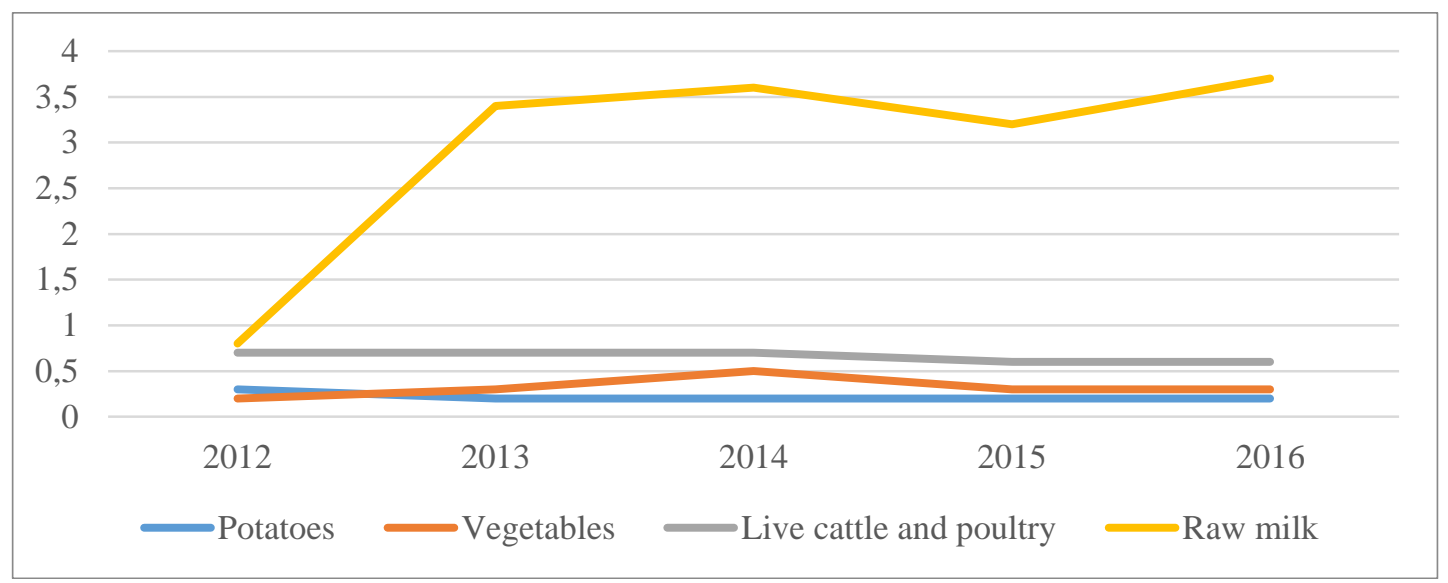

Figure 1. The role of ACCs in the sale of the main types of agricultural products, \% by years Source: On the State of Rural Areas in the Russian Federation in 2016. Annual Report on the Results of Monitoring. (2018).

An analysis of the presented graph shows that over the period under review, only the sale of milk increased through co-operatives. This growth, starting in 2013, was achieved through the implementation of programs for the development of "milk" cooperation in the following regions: Chelyabinsk Region, Republic of Sakha (Yakutia), Chuvash Republic, Tyumen Region, Ulyanovsk Region, Belgorod Region, Republic of Tatarstan, Lipetsk Region, Udmurtian Republic, Irkutsk Region (Pakhomov, 2014).

Assessing the measures of the governmental policy aimed at supporting consumer cooperation organizations and its competitors represented by ACCs, the authors will consider two of its areas: the taxation policy and the governmental financial support policy.
Speaking of the measures of state financial support for consumer cooperation organizations, it can be stated that it has not been introduced over the last time (10 years). At the same time, ACCs are actively enjoying such measures.

From 2008 to 2012, within the framework of the State Program, the interest was compensated on credits and loans by agricultural consumer cooperatives (except for credit loans) at the level of the Bank of Russia's refinancing rate. This measure was widely used in attracting by ACCs of borrowings for various purposes (supplying members with resources, etc.). Since 2013, this measure was retained in the new State Program only for long-term (investment) credits, available for an extremely small number of co-operatives. 


\section{AMAZONIA
Investiga}

A qualitatively new stage in supporting agricultural consumer co-operatives is associated with the beginning of the provision of grants to them for the formation and development of the material and technical facilities.

The quantitative parameters of a grant were determined as follows: "the maximum grant for the development of the material and technical facilities per one agricultural consumer cooperative shall be determined by the constituent entities of the Russian Federation in an amount not exceeding 70 million rubles, and not more than 60 percent of the costs of developing the material and technical facilities of an agricultural consumer co-operative". The distribution of grants at the regional level on a competitive basis was provided for.

Since January 1, 2017, in connection with the fundamental changes in the mechanism for providing state support to the agro-industrial sector (transition to the so-called "uniform subsidy"), the regulatory framework for the provision of grants for the development of the material and technical facilities in agricultural consumer co-operatives has also changed. Since 2017, grant support issues not directly regulated by the State Program were transferred to the level of the constituent entities of the Russian Federation. The state program retained the general definitions of a grant, an agricultural consumer co-operative, the maximum amount of support provided, and the maximum ratio of state funds to a co-operative's funds.

Over the 2.5 years of the implementation of measures to provide grants to agricultural consumer co-operatives for the development of the material and technical facilities, 425 cooperatives from more than 60 regions of the Russian Federation have used this support. The total amount of funds for the grants is about 4 billion rubles, including 2.8 billion rubles funded by the federal budget (On the state of rural areas in the Russian Federation in 2016, 2018).

In addition, ACCs have government support at the regional level. As of the 1st quarter of 2018, 25 regional programs were operating, in force till 2020 .

In the field of taxation, ACCs, in comparison with consumer co-operatives, also have a potential advantage, as they may apply special tax regimes, in particular, the uniform agricultural tax. Tax incentives at the regional level are practically absent for both ACCs and consumer co-operatives. The only exception is the incentive for ACCs established in the Kaluga Region for the regional part of income tax at the level of 13.5 percent for investors who have made share contributions to agricultural organizations.

To compare the effectiveness of state support for rural cooperation, one can refer to the experience of China. After the adoption of the series of laws on Specialized Farm Co-operatives in China in 2007, the number of Chinese co-operatives increased, reaching almost 1.5 million in 2015, and there was a tendency to diversify into various types (Huang et al., 2014; Kong, 2013).

\section{Conclusions}

Thus, the development of rural cooperation allows solving employment issues, increasing sales of agricultural products, increasing the making of processed agricultural products, increasing rural incomes, and partially solving poverty issues.

Summarizing the above, one can draw the following conclusions:

1) despite the fact that the volume of procurement activities of consumer cooperation organizations is not large, it has, along with other factors, a positive impact on the living standards of the rural population of Russia;

2) the following factors impede the development of procurement activities:

- reduction in the number of material and technical facilities required for the implementation of this activity;

- competition by other procurement players;

- lack of public policy measures aimed at supporting this type of activity of consumer cooperation organizations;

- one of the main competitors of consumer cooperation organizations in the field of procurement is ACCs, using organizational, legislative, financial and other types of support at the state and regional levels.

In the authors' opinion, for the successful development of this type of activity, consumer cooperation organizations need:

- to conclude agreements with large consumers of harvested products, ready to purchase on a stable basis over a long period;

- to significantly expand the material and technical facilities necessary for the implementation of procurement activities; 
- to ensure the support by regional and federal authorities, including that in matters of financing investments.

\section{Bibliographic references}

About the Central Union of Russia (2019). Official website of the Central Union of Russia. Available at: https://rus.coop/ru/about/ (accessed September, 2019).

Akhmetov, V.Ya., Baigildina, A.U. and Idrisova, A.T. (2017). Problems and Prospects of Development of Cooperation in the Countryside (on the Example of the South and North-Eastern Regions of the Republic of Bashkortostan). Economy and Entrepreneurship, 85, 309-315.

Ariyaratne, C.B., Featherstone, A.M., Langemeier, M.R. and Barton, D.G. (1997). An Analysis of Efficiency of Midwestern Agricultural Co-operatives. Western Agricultural Economics Association Annual Meeting. Reno/Sparks, Nevada, 1-15.

Drivas, K. and Giannakas, K. (2006). Agricultural Co-operatives and QualityEnhancing R\&D in the Agri-Food System. The 98th EAAE Seminar "Marketing Dynamics within the Global Trading System: New Perspectives", 1-36.

Drivas, K. and Giannakas, K. (2007). The Effect of Marketing Co-operatives on CostReducing Process Innovation Activity. American Agricultural Economics Association Annual Meeting, 1-34. Portland, Oregon

Falyakhov, R. (2018). Poverty in Russia: Tens of Millions Beyond. Gazeta.Ru. Available at: https://www.gazeta.ru/business/2018/05/09/117 45109.html (accessed September, 2020).

Federal State Statistics Service. (2019). Social and Economic Situation of Russia. Available at: https://nangs.org/analytics/rosstat-dokladsotsialno-ekonomicheskoe-polozhenie-rossiiitogovyj-pdf (accessed September, 2019).

Fulton, M. and Giannakas, K. (2001). Organizational Commitment in a Mixed Oligopoly: Agricultural co-Operatives and Investor-Owned Firms. American Journal of Agricultural Economics, 83(5), 1258-1265, https://doi.org/10.1111/0002-9092.00276

Giannakas, K. and Fulton, M.E. (2003). Agricultural Co-operatives and Cost-Reducing R\&D in the Agri-Food System. American Agricultural Economics Association Annual Meeting, 1-30. Montreal, Canada.

Giannakas, K. and Fulton, M.E. (2005). Process Innovation Activity in a Mixed Oligopoly: The Role of Co-operatives. American Journal of Agricultural Economics, 87(2), 406-422, https://doi.org/10.1111/j.1467-

8276.2005.00731.x
Goodman, D., DuPuis, M. and Goodman, M. (2011). Alternative Food Networks: Knowledge, Practice and Politics. London: Routledge.

Huang, Z.H., Wu, B. and Xu, X.C. (2014). "Ideal Types of Co-operatives" and Their Practical Logics. Agricultural Economics Issues, 35(10), 8-18.

International Co-operative Alliance. (1995). What Is a Cooperative? Available at: https://www.ica.coop/en/what-co-operative-0 (accessed September, 2019).

Ji, C., Jia, F. and Xu, X. (2018). Agricultural Cooperative Sustainability: Evidence from Four Chinese Pig Production Co-operatives. Journal of Cleaner Production, 197, 1095-1107, http://dx.doi.org/10.1016/j.jclepro.2018.06.279

Kong, X. (2013). Thinking on Development of Various Kinds of Co-operatives. China Farmers' Co-operatives, 7, 26-28.

Koopmans, M.E., Rogge, E., Mettepenningen, E., Knickel, K. and Sumane, S. (2018). The Role of Multi-Actor Governance in Aligning Farm Modernization and Sustainable Rural Development. Journal of Rural Studies, 59, 252-262,

https://doi.org/10.1016/j.jrurstud.2017.03.012

Kumar, V., Wankhede, K.G. and Gena, H.C. (2015). Role of Co-operatives in Improving Livelihood of Farmers on Sustainable Basis. American Journal of Educational Research, 3 (10), 1258-1266.

Liang, Q., Hendrikse, G., Huang, Z. and Xu, X. (2015). Governance Structure of Chinese Farmer Co-operatives: Evidence from Zhejiang Province. Agribusiness, 31 (2), 198-214, https://doi.org/10.1002/agr.21400

Luo, J.L., Guo, H.D. and Jia, F. (2017). Technological Innovation in Agricultural Cooperatives in China: Implications for AgroFood Innovation Policies. Food Policy, 73(C), 19-33,

https://doi.org/10.1016/j.foodpol.2017.09.001

Marsden, T. (2012). Third Natures? Reconstituting Space through Place-Making Strategies for Sustainability. International Journal of Sociology of Agriculture and Food, 19 (2), 257-274.

On the State of Rural Areas in the Russian Federation in 2016 (2018). Annual Report on the Results of Monitoring. Moscow: Rosinformagrotech. Available at: https://rosinformagrotech.ru/data/anons/vyshloizdanie-o-sostoyanii-selskikh-territorij-v-

rossijskoj-federatsii-v-2016-godu (accessed September, 2019).

Pakhomov, V.M. (2014). Organizational and Economic Models of Dairy Cooperation Development in Russia. Fundamental and Cooperative Applied Research of Cooperative 


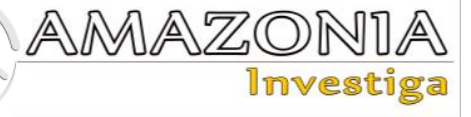

Sector of Economy, 1, 19-26. Available at: https://www.ruc.su/upload/science/journal/12014.pdf (accessed September, 2019).

Pinkovetskaia, I., Arbeláez-Campillo, D., Rojas-Bahamón, M., Novikov, S., \& Veas Iniesta, D. (2020). Social values of entrepreneurship in modern countries. Amazonia Investiga, 9(28),

6-13.

https://doi.org/10.34069/AI/2020.28.04.1

Ploeg van der, J.D. (2008). The New Peasantries: Struggles for Autonomy and Sustainability in an Era of Empire and Globalization. London: Earth Scan.

Ploeg van der, J.D. (2013). Peasants and the Art of Farming. A Chayanovian Manifesto. Fernwood Publishing, Halifax and Winnipeg.

RIA Rating Agency. (2018). Rating of Social and Economic Situation of the Constituent Territories of the Russian Federation for 2017. Moscow: RIA Rating Agency, LLC. Available at: http://vid1.rian.ru/ig/ratings/rating_regions_201 8.pdf (accessed September, 2019).

Rzhanitsyna, L.S. (2013). How to Reduce Poverty in Russia? Journal of the New Economic Association, 18, 180-183. Available at: http://www.econorus.org/repec/journl/2013-18180-183r.pdf (accessed September, 2019).
Schram, S.G. (2007). Cooperatives: Pathways to Economic, Democratic and Social Development in the Global Economy. The U.S. Overseas Cooperative Development Council. Available at: http://www.nrecainternational.coop/wpcontent/uploads/2016/11/Pathwayspaper.pdf (accessed September, 2019).

Statistical portal (2019). Population of Russia: Number, Dynamics, Statistics Available at: http://www.statdata.ru/russia (accessed September, 2019).

Tkach, A.V. and Balalova, E.I. (2017). The main vectors of activity of The Central Union of Russia in the Food Market. Fundamental and applied research studies of the economics cooperative sector, (3), 10-15. Available at: https://www.ruc.su/upload/medialibrary/810/81 00dfa6a30c0bdeffe4a9a11908d40c.pdf (accessed May, 2021)

Wiskerke, J.S.C. (2009) On Places Lost and Places Regained: Reflections on the Alternative Food Geography and Sustainable Regional Development. International Planning Studies, 14(4), 369-387, https://doi.org/10.1080/13563471003642803 